\title{
Equine multinodular pulmonary fibrosis in southern Brazil: pathology and differential diagnosis ${ }^{1}$
}

\author{
Pablo Estima-Silva ${ }^{2}$, Clairton Marcolongo-Pereira ${ }^{3}$, Bianca Lemos dos Santos ${ }^{2}$, \\ Ana Carolina Barreto Coelho², Lorena Alvariza Amaral ${ }^{4}$, Ailam Lim ${ }^{5}$, Steven R. \\ Bolin $^{5}$ and Ana Lucia Schild ${ }^{6 *}$
}

\begin{abstract}
Estima-Silva P., Marcolongo-Pereira C., Santos B.L., Coelho A.C.B., Amaral L.A., Lim A., Bolin S.R. \& Schild A.L. 2017. Equine multinodular pulmonary fibrosis in southern Brazil: pathology and differential diagnosis. Pesquisa Veterinária Brasileira 37(11):1247-1252. Laboratório Regional de Diagnóstico, Faculdade de Veterinária, Universidade Federal de Pelotas, Campus Universitário s/n, Pelotas, RS 96010-900, Brazil. E-mail: alschild@terra.com.br

Equine multinodular pulmonary fibrosis (EMPF) diagnosed at the Laboratório Regional de Diagnóstico of Faculdade de Medicina Veterinária, Universidade Federal de Pelotas (LRD/UFPel), is described. Differential aspects of other pulmonary diseases in horses with pneumonia and interstitial fibrosis were discussed. The disease occurred in a 15-year-old equine that presented with clinical signs of respiratory distress, intermittent fever, anorexia, and dyspnea. Macroscopically, there was enlargement of the lungs with whitish, pale, firm and well-delimited nodules, approximately $7-10 \mathrm{~cm}$ in diameter, distributed throughout the parenchyma. Histologically, the lung nodules had alveolar spaces with walls covered by cuboidal epithelium containing macrophages, neutrophils, lymphocytes, hyperplasia of type II pneumocytes and, eventually, multinucleated giant cells. The interstitium was markedly thickened by mature fibrous connective tissue and collagen. There were intranuclear inclusion bodies in the macrophages. The PCR technique for detecting the EHV-5 DNA was positive. In a retrospective study of pneumonia cases in horses with interstitial fibrosis diagnosed in the LRD/UFPel, two animals had macroscopic and histological lesions similar to those with EMPF, but they were negative for EHV-5 in PCR. Four cases diagnosed with pneumonia and interstitial tissue fibrosis had a histological pattern that was different from that observed in the EMPF animal, thus eliminating the possibility of EMPF. It is concluded that EMPF is a sporadic disease that should be considered in cases of respiratory disease in horses. Reports of such cases are important to alert technicians about the occurrence of rare diseases in Brazil. It is also necessary to establish the true role of EHV-5 in the pathogenesis of EMPF. Cases of pulmonary fibrosis such as EMPF, in which the virus is not present, should be studied to establish whether it could be an idiopathic form of the disease.
\end{abstract}

INDEX TERMS: Equine multinodular pulmonary fibrosis, pathology, differential diagnosis, disease of horses, retrospective study.

RESUMO.- [Fibrose pulmonar multinodular em equinos no Sul do Rio Grande do Sul: patologia e diagnóstico diferencial.] Descreve-se a fibrose multinodular pulmonar

\footnotetext{
${ }^{1}$ Received on March 13, 2017.

Accepted for publication onMarch 28, 2017.

${ }^{2}$ Programa de Pós-Graduação em Veterinária, Faculdade de Veterinária (FV), Universidade Federal de Pelotas- (UFPel) Campus Capão do Leão, Pelotas, RS 96010-900, Brazil.

${ }^{3}$ Faculdade de Veterinária, Centro Universitário Ritter dos Reis (UniRitter), Rua Orfanotrofio 555, Alto Teresópolis, Porto Alegre, RS 90840-440, Brazil.
}

equina (EMPF) diagnosticado no Laboratório Regional de Diagnóstico da Faculdade de Veterinária da Universidade Federal de Pelotas. Foram discutidos a patologia da doen-

\footnotetext{
${ }^{4}$ Médica Veterinária Autônoma, Avenida da Paz 217, casa 2, Bairro Areal, Pelotas, RS 96077-210, Brazil.

${ }^{5}$ Diagnostic Center for Population and Animal Health, Michigan State University, 4125 Beaumont Road, Lansing, MI 48910-8104, USA.

${ }^{6}$ Laboratório Regional de Diagnóstico, Faculdade de Veterinária, UFPel, Campus Universitário s/n, Pelotas, RS 96010-900,. *Corresponding author: alschild@terra.com.br
} 
ça e os aspectos diferenciais de outras enfermidades pulmonares de equinos que cursam com pneumonia e fibrose intersticial. A doença ocorreu em um equino sem raça definida de 15 anos de idade que apresentou sinais clínicos de dificuldade respiratória febre intermitente, anorexia e dispneia, com evolução de aproximadamente 10 dias. Macroscopicamente havia aumento de volume dos pulmões e nódulos esbranquiçados, pálidos, firmes e bem delimitados, de aproximadamente $7-10 \mathrm{~cm}$ de diâmetro, distribuídos pelo parênquima. Histologicamente, o tecido pulmonar apresentava nódulos caracterizados pela presença de espaços alveolares, com paredes revestidas por epitélio cuboidal achatado, contendo macrófagos e neutrófilos e havia, também, linfócitos e hiperplasia de pneumócitos tipo II e eventualmente células gigantes multinuacleadas. 0 interstício estava acentuadamente espessado por tecido conjuntivo fibroso maduro e por colágeno. Havia corpúsculos de inclusão intranucleares em macrófagos. A técnica de PCR para detecção do DNA de herpes vírus equino-5 (EHV5) resultou positiva. Em um estudo retrospectivo de casos de pneumonia com fibrose intersticial diagnosticados no LRD entre 2000 e 2015, dois equinos apresentaram lesões macroscópicas e histológicas similares às de EMPF, porém resultaram negativos na PCR para detecção de EHV-5. Quatro casos de pneumonia com fibrose do tecido intersticial apresentaram padrão histológico diverso da EMPF descartando-se a possibilidade de tratar-se da doença. Conclui-se que EMPF é uma enfermidade esporádica, no entanto deve ser levada em consideração em casos de doença respiratória em equinos. A descrição dos casos diagnosticados é importante para alertar técnicos sobre a ocorrência da mesma no Brasil. É necessário estabelecer o real papel do EHV-5 na patogenia da doença. Casos de fibrose pulmonar semelhantes à EMPF em que não esteja presente o vírus, devem ser estudados a fim de ficar estabelecido se poderia ser uma forma idiopática da mesma doença.

TERMOS DE INDEXAÇÃO: Fibrose pulmonar multinodular, equinos, patologia, diagnóstico diferencial, doenças pulmonares, herpesvírus equino-5.

\section{INTRODUCTION}

Equine multinodular pulmonary fibrosis (EMPF) is a rare, spontaneous fibrosing pulmonary disease in horses that is associated with pulmonary infection by equine herpesvirus 5 (EHV-5); it was first reported in the United States (Williams et al. 2007) and has been recently documented in European countries (Poth et al. 2009). It mainly occurs in adult and senile animals; however, rare cases have been described in young animals (Ainsworth 2012). In Brazil, the disease was diagnosed for the first time in a seven-year-old Thoroughbred mare that died after presenting with chronic respiratory disease characterized by tachypnea, dyspnea and cough accompanied by weight loss, anorexia and intermittent fever (Panziera et al. 2014).

The etiology of EMPF is associated with EHV-5 infection. However, the specific role of this agent in the development of pathology has not yet been elucidated (Hart et al. 2008). There are two distinct gross characteristics of the disease. The most common characteristic presents as numerous coalescing nodules of fibrosis, ranging from 1-5 $\mathrm{cm}$ in diameter. The nodules are pale and moderately firm, and the edges are discreetly evident (Williams et al. 2007). A lesser common gross characteristic consists of multiple nodules that are separated by unaffected lung areas. These nodules can be confused with a neoplastic process and they are larger than the coalescing form of the disease (up to $10 \mathrm{~cm}$ in diameter); additionally, they are pale and firm (Williams et al. 2007). Histological lesions are confined to the alveolar pulmonary parenchyma, regardless of the gross presentation. The nodules consist of well-organized mature collagen with mixed infiltration of inflammatory cells, mainly lymphocytes and, to a lesser extent, macrophages, neutrophils and occasional eosinophils (Williams et al. 2007). An alveolar-like architecture is preserved and delimited by cuboidal epithelial cells. In the alveolar spaces, there is an inflammatory infiltrate of neutrophils and macrophages. Rarely, large macrophages with abundant eosinophilic cytoplasm and eosinophilic intranuclear viral inclusion are observed (Williams et al. 2007).

The aim of the present study was to describe the pathology of equine multinodular pulmonary fibrosis diagnosed in the Laboratório Regional de Diagnóstico of the Universidade Federal de Pelotas (LRD/UFPel) and to discuss its differences with other equine pulmonary fibrosing diseases diagnoses in LRD/UFPel between the years of 2000 and 2015.

\section{MATERIALS AND METHODS}

Lung fragments from a horse were sent to the Laboratório Regional de Diagnóstico of the Universidade Federal de Pelotas (LRD/ UFPel) for diagnosis. The material was fixed in $10 \%$ buffered formalin, cleaved and routinely processed. Histological sections with a thickness of $5 \mu \mathrm{m}$ were stained with hematoxylin and eosin and Masson's trichrome. Due to the suspicion for equine multinodular pulmonary fibrosis, paraffin blocks were sent to Michigan State University's Diagnostic Center for Population and Animal Health for HVE-5 detection by PCR, and DNA extraction was performed according to the technique described by Panziera et al. (2014).

Then, a retrospective study of respiratory diseases with interstitial fibrosis diagnosed in horses in the LRD, from 2000 to 2015, was performed. All LRD/UFPel necropsy protocols were reviewed, and the epidemiological data, clinical signs and description of the gross and histological pathology of each case were recovered. New histological slides were made from the paraffin blocks of the LRD/UFPel collection and stained with hematoxylin and eosin. The presence of fibrosis was observed by Masson's trichrome staining. Two other cases were also sent to Michigan State University's Diagnostic Center for Population and Animal Health for equine herpesvirus 5 detection by the same technique.

\section{RESULTS}

Fragments of the lung from a free range, mixed breed, 15-year-old horse were sent to the LRD/UFPel for analysis. The animal had a history of respiratory difficulty that resolved with the use of bronchodilators one year before death. Later, the horse had intermittent fever, anorexia and dyspnea over approximately 10 days. Ultrasound revealed the presence of nodular areas that were suggestive of lung 
abscesses. After a week with these signs, the horse died and was necropsied on the property. Gross lesions were characterized by enlargement of the lungs, which had rib printing and whitish, firm, well-defined nodules that were approximately $7-10 \mathrm{~cm}$ in diameter. The nodules were distributed throughout the parenchyma (Fig.1A). Histologically, the lung had nodules that were characterized by the presence of alveolar spaces containing macrophages, neutrophils, lymphocytes and hyperplasia of type II pneumocytes (Fig.1B). Eventually, giant multinucleated cells could be observed. The alveolar walls were delimited by flattened epithelial cells, and the interstitium in these areas was markedly thickened by mature fibrous connective tissue and collagen that was better demonstrated by Masson's trichrome staining (Fig.1C). Intranuclear inclusion bodies were observed in macrophages. The PCR for detecting EHV5 DNA was positive in this case.

The retrospective study identified six cases, numbered one to six, in order of arrival to the LRD/UFPel with a diagnosis of pneumonia. All cases were characterized by the presence of fibrous connective tissue that was diffusely distributed around the alveoli and in the pulmonary inters-
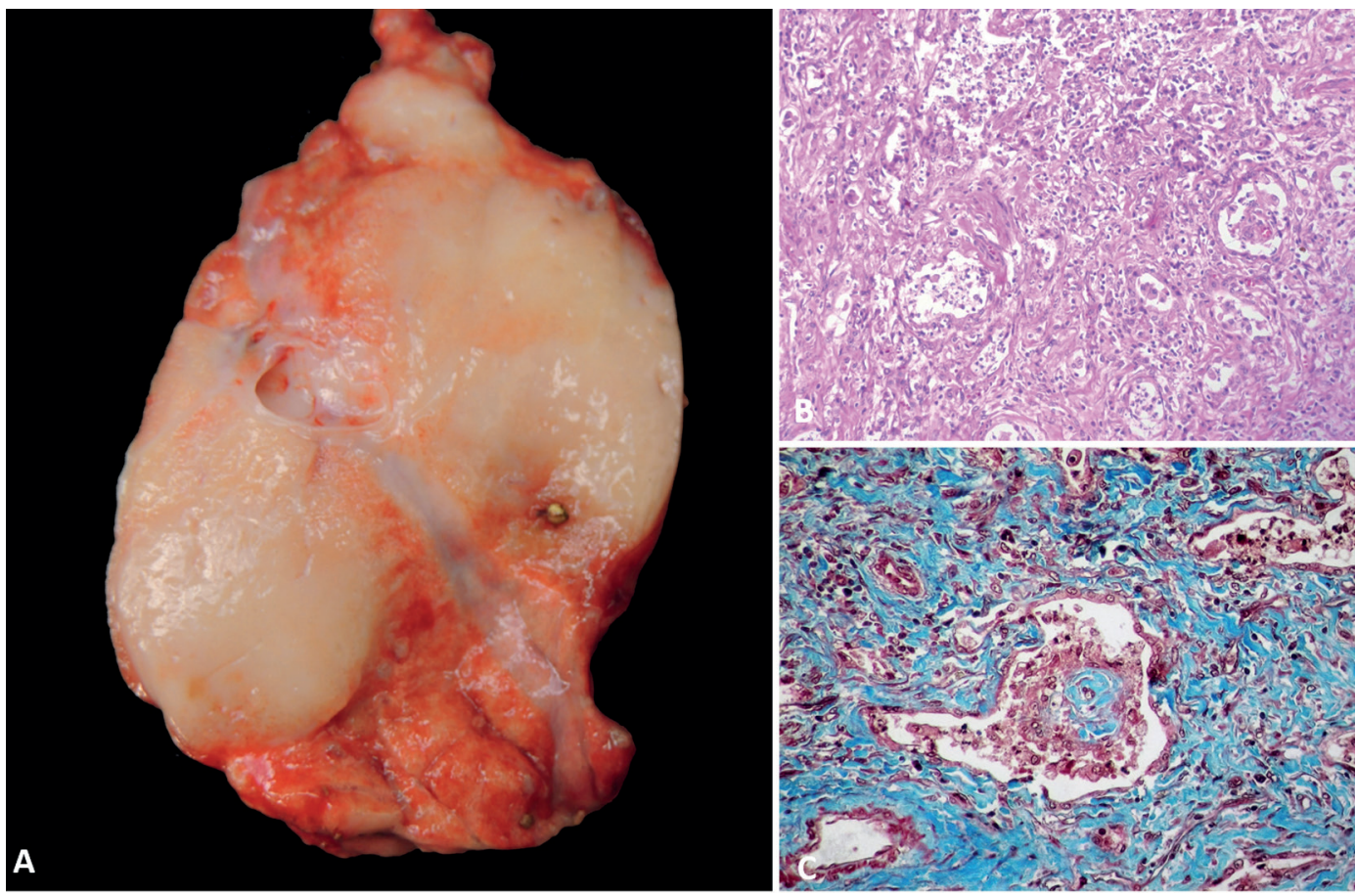

Fig.1. (A) Equine lung with multinodular pulmonary fibrosis. There are whitish, firm and well-defined nodules that were approximately $7-10 \mathrm{~cm}$ in diameter distributed in the parenchyma. (B) Histological section of the lung showing alveolar spaces containing macrophages, neutrophils, lymphocytes and hyperplasia of type II pneumocytes. HE, obj.20x. (C) Mature fibrous connective tissue around alveolar spaces. TM, obj.40x.
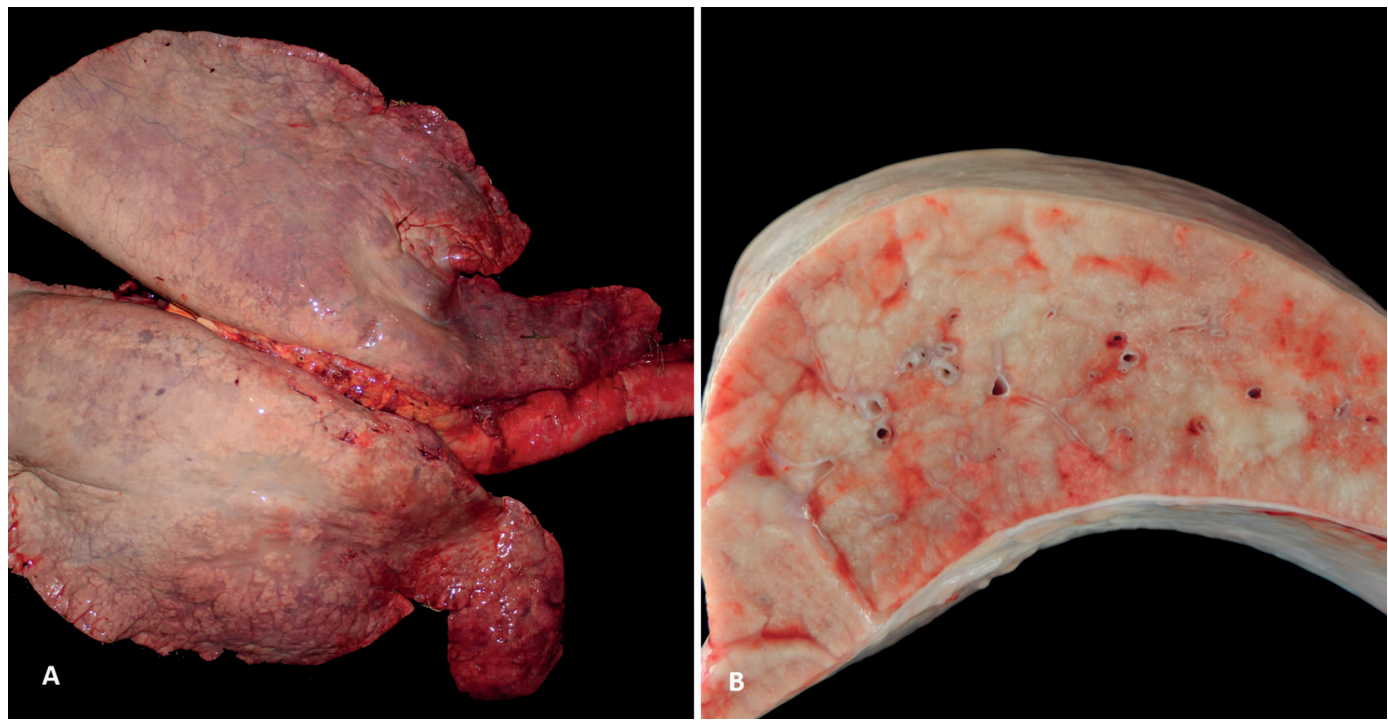

Fig.2. (A) Equine lung presenting whitish, pale and firm nodules distributes in the parenchyma. (B) The cut surface of the lung showing coalescing nodular areas. 
titial tissue. Four mixed-breed horses, between eight and 15 years of age (cases 1, 2, 3, and 5) were identified; Mangalarga Marchador (case 4) was 22 years old, and a Criollo breed horse (case 6) was four months old.

The clinical signs observed in two horses (cases 4 and 6) were characterized by tachypnea and nasal secretion with disease progression from one to four weeks. Ultrasound examination performed on case 6 revealed areas suggestive of abscesses. This foal was treated with antibiotics for one month, but no improvement was observed. The horse in case 5 was in an urban setting and had clinical signs of nasal secretion, mandibular trismus and permanent decubitus. Three other horses (cases 1, 2 and 3) were from a slaughterhouse and lacked a clinical history; only the lungs were sent to the laboratory for examination.

Gross lesions in two cases (cases 4 and 6) were characterized by enlargement of the lungs with rib impressions and the presence of whitish, pale and firm nodules distributed in the parenchyma. Fibrin was also observed on the surface of the organ. In both horses, the nodules were coalescing and ranged from 1 to $5 \mathrm{~cm}$ (Fig.2A,B). In one case (case 5), there were cavitations in the lung parenchyma surrounded by firm, whitish connective tissue. One equine (case 2) had an increase the lung volume and a firm cut surface. In another horse (case 3), the lungs were congested and had suppurative foci; in yet another (case 1), there was no macroscopic description in the necropsy protocol.
Histologically, cases 4 and 6 had coalescent nodules with alveolar spaces delimited by epithelial cells containing neutrophils, macrophages, and type II pneumocyte proliferation (Fig.3A,B). Moreover, there was mature fibrous tissue proliferation surrounding the alveolar spaces, which was best demonstrated with Masson's trichrome staining (Fig.3C,D). In cases 1, 2, 3 and 5, there was a loose connective tissue proliferation around the alveoli, which had thin walls with mixed inflammatory infiltrate in the interior. In case 5, there was inflammatory infiltration of neutrophils in the interstitium. PCR for detecting EHV-5 DNA was negative in cases 4 and 6.

\section{DISCUSSION}

Equine multinodular pulmonary fibrosis associated with EHV-5 infection was confirmed by the identification of viral DNA by PCR in lung fragments of a 15-year-old mixed-breed equine lung sent to the LRD/UFPel. The clinical signs observed in the horse with EMPF in the present study were non-specific, which is similar to the cases of disease described in the literature. Other reports of the disease mentioned clinical signs, such as an increased respiratory rate, weight loss (Verryken et al. 2010), fever, tachycardia, nasal secretion (Dunowska et al. 2014 Panziera et al. 2014), reluctance to move, tachypnea and discrete cough (Back et al. 2012). These clinical signs occur in several respiratory diseases in horses. In a study on the detection of EHV-5 in

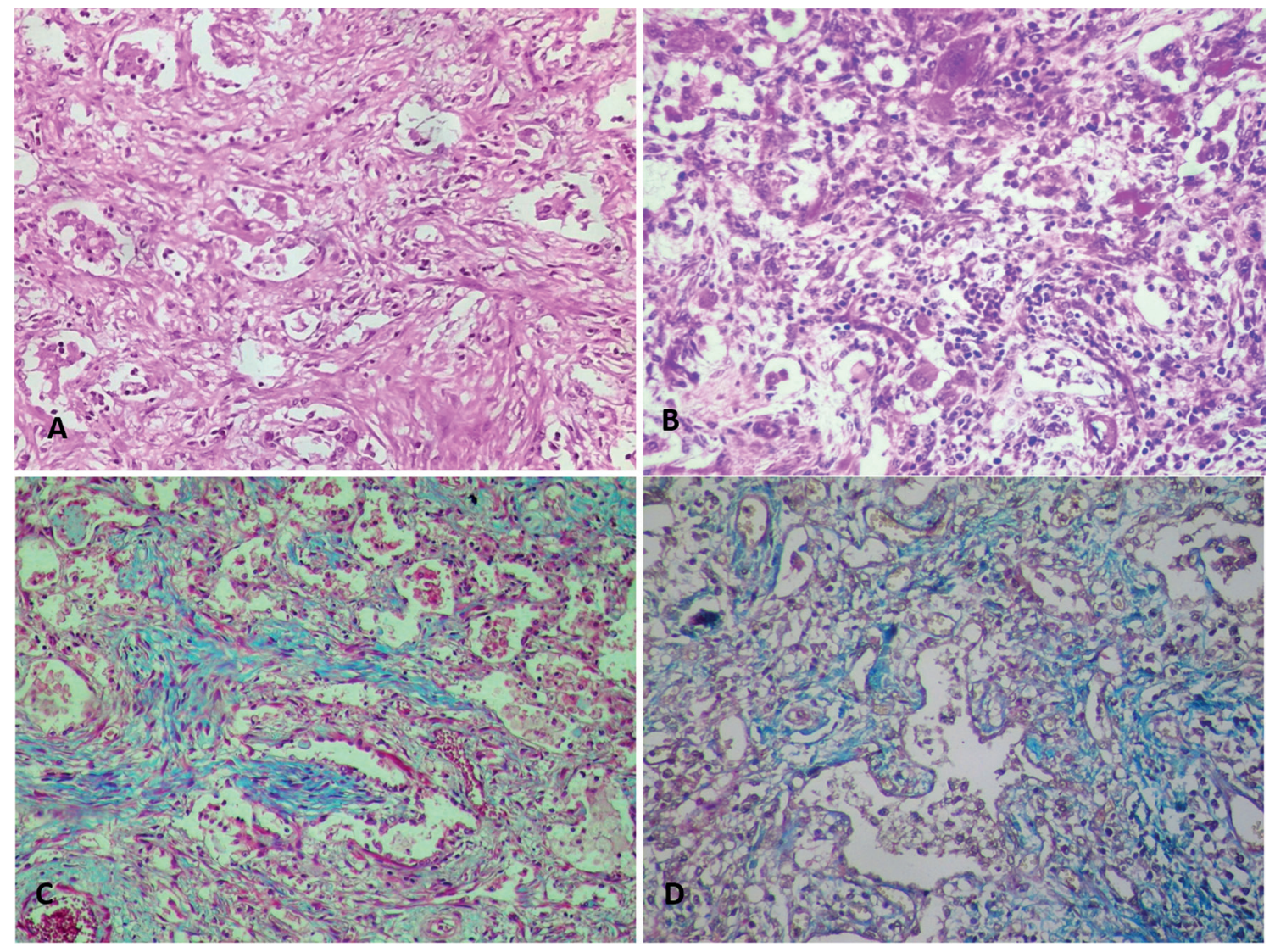

Fig.3. (A) Histological section of lung shown in Figure 2A. The alveolar spaces show inflammatory cells and connective tissue proliferation. HE, obj.20x. (B) Histological section of lung shown in Figure 2B. There is proliferation of type II pneumocytes and inflammatory cells within alveoli. HE, obj.20x. (C,D) There is a marked proliferation of fibrous tissue around the alveolar spaces. TM, obj.20x. 
horses with EMPF and other respiratory diseases, the clinical signs observed in different groups were similar (Pusterla et al. 2015), thus demonstrating their non-specificity. EMPF is difficult to diagnose in a living animal and may be suspected based on clinical and radiological examination, lung biopsy, and identification of EHV-5 by tracheal lavage with PCR analysis (Williams et al. 2013).

In an EMPF report in Belgium, the authors considered neoplasia; idiopathic granulomatous pneumonia; and bacterial, fungal or parasitic pneumonias in the differential diagnosis based on the clinical signs and radiological and ultrasonographic findings (Verryken et al. 2010). In the case of EMPF described in this study, there was suspicion for lung cancer or an abscess, as observed by ultrasonography. Ultrasonography performed on a foal (case 6) with respiratory signs suggested the presence of abscesses in the lung, and the suspicion was for Rhodococcus equi infection because this disease causes pulmonary abscesses in foals from one to six months of age (Giguère \& Prescott 1997). Other pneumonias with fibrosis can be differentiated by the macroscopic and histological pattern of the lesions, as evidenced in the present study. Of the six cases with a histological description of pneumonia and interstitial fibrosis, only two had a histological pattern such as that described for EMPF. These two cases were negative for EHV-5. Nevertheless, EMPF cannot be ruled out in these two cases that lack EHV-5 DNA amplification. It has been observed a negative effect of prolonged fixation on PCR products. Periods of fixation greater than 45 days produce negative or weakly positive results with the PCR technique (Crawford et al. 1999).

The gross lesions observed in the horse with EMPF in this paper were characterized as a less frequent form of the disease, as mentioned in a previous description (Williams et al. 2007). Comparing the case with EMPF and the retrospective study cases, four cases had different macroscopic lesions, which made it possible to rule out EMPF. However, two cases had macroscopic lesions that are characteristic of the disease. One case was a four-month-old foal with gross lesions similar to those mentioned by other authors (Panziera et al. 2014). The lesions in this foal were characterized as the most frequent pattern of the disease (Williams et al. 2007). It is noteworthy that the disease is rare in young animals and few cases have been diagnosed in horses under 4 years of age (Ainsworth 2012).

The histological lesions observed in the equine with EMPF were similar to prior descriptions (Williams et al. 2007, Panziera et al. 2014). In contrast, in the two cases in which the virus was not detected, the similarity of the histological lesions suggests that they have the same disease or are an idiopathic form of pulmonary fibrosis. The cuboidal epithelium that lines the alveoli, the presence of well-organized mature fibrous tissue in the interstitium around the alveoli, and the presence of intranuclear inclusion bodies in macrophages have been noted in reports of the disease from different countries (Williams et al. 2007, Verryken et al. 2010, Back et al. 2012, Panziera et al. 2014). EHV-5 infection plays a key role in the development of EMPF, but the mechanism by which the virus causes the disease is not fully understood. However, there is strong evidence indicating EVH-5 plays a primary or complicating role in the etiology of the disease. Most reports have mentioned amplification of viral DNA in the lungs of affected animals (Hart et al. 2008, Wong et al. 2008). EHV-5 was detected in six clinical cases of the disease and in 24 necropsied horses. The virus was detected in nasal swabs, peripheral blood mononuclear cells and various tissues of healthy horses and foals (Ainsworth 2012).

Based on this and other studies, EMPF appears to have a sporadic nature (Verryken et al. 2010, Back et al. 2012, Dunowska et al. 2014). The virus prevalence is relatively high in some countries and may be isolated in numerous horses or in some populations, which contrasts the small number of diagnosed EMPF cases (Verryken et al. 2010). In Brazil, there are no data on the prevalence of EVH-5 infection, and this is the second confirmed report of the disease in at least one of the equines with similar gross and histological lesions. The other case was also diagnosed in Rio Grande do Sul by Panziera et al. (2014).

\section{CONCLUSIONS}

EMPF is present in Rio Grande do Sul, and despite its sporadic nature, it should be considered in equine chronic pneumonia cases with fibrosis.

Because EMPF is a recently described disease, it is essential to report new cases as they are diagnosed. Veterinarians should be aware of its occurrence in the Rio Grande do Sul state and in other regions of the country.

More studies are needed to determine the role of EHV5 in the disease pathogenesis. Cases of pulmonary fibrosis similar to EMPF in which no viral DNA is detected should be studied in further detail to determine whether the horse has an idiopathic form of pulmonary fibrosis.

\section{REFERENCES}

Ainsworth D.M. 2012. Equine Multi-nodular Pulmonary Fibrosis (EMPF). Proc. 18th Annual Meeting of the Italian Association of Equine Veterinarians, Bologna, IVIS, p.17-21.

Back H., Kendall A., Grandón R., Ullman K., Treiberg-Berndtsson L., Ståhl K. \& Pringle J. 2012. Equine multinodular pulmonary fibrosis in association with asinine herpesvirus type 5 and equine herpesvirus type 5: a case report. Acta Vet. Scand. 2012:54-57.

Crawford T.B., Hong L.i \& O’Toole D. 1999. Diagnosis of malignant catarrhal fever by PCR using formalin-fixed, paraffin-embedded tissues. J. Vet. Diagn. Invest. 11(2):111-116.

Dunowska M., Hardcastle M.R. \& Tonkin F.B. 2014. Identification of the first New Zealand case of equine multinodular pulmonary fibrosis. N.Z. Vet. J. 62(4):226-231.

Giguère S. \& Prescott J.F. 1997. Clinical manifestations, diagnosis, treatment, and prevention of Rhodococcus equi infections in foals. Vet. Microbiol. 56:313-334.

Hart K.A., Barton M.H., Williams K.J., Flaminio M.J.B.F. \& Howerth E.W. 2008. Multinodular pulmonary fibrosis, pancytopenia and equine herpesvirus-5 infection in a Thoroughbred gelding. Equine Vet. Educ. 20(9):470-476.

Panziera W., Giaretta P.R., Galiza G.J.N., Lim A., Bolin S.R., Borges C.H., Fighera R.A. \& Barros C.S.L. 2014. Equine multinodular pulmonary fibrosis associated with equine Herpesvirus 5 in a horse in Brazil. Braz. J. Vet. Pathol. 7(1):17-20.

Poth T., Niedermaier G. \& Hermanns W. 2009. Foal-related risk factors 
associated with development of Rhodococcus equi pneumonia on farms with endemic infection. Vet. Med. Austria 96:203-208.

Pusterla N., Magdesian K.G., Mapes S.M., Zavodovskaya R. \& Kass P.H. 2015. Assessment of quantitative polymerase chain reaction for equine herpesvirus-5 in blood, nasal secretions and bronchoalveolar lavage fluid for the laboratory diagnosis of equine multinodular pulmonary fibrosis. Equine Vet. J. 49(1):34-38.

Verryken K., Saey V., Maes S., Borchers K., Van de Walle G., Ducatelle R. \& Deprez P. 2010. First report of multinodular pulmonary fibrosis associated with equine herpesvirus 5 in Belgium. Vlaams Diergeneeskundig Tijdschrift 79:297-301.

Williams K.J., Robinson N.E., Lim A., Brandenberger C., Maes R., Behan
A. \& Bolin S.R. 2013. Experimental induction of pulmonary fibrosis in horses with the gammaherpesvirus equine herpesvirus 5. Plos One 8(10):e77754.

Williams K.J., Maes R., Del Piero F., Lim A., Wise A., Bolin D.C., Caswell J., Jackson C., Robinson N.E., Derksen F.M.A., Scott M.A., Uhal B.D., Li X., Youssef S.A. \& Bolin S. 2007. Equine multinodular pulmonary fibrosis: a newly recognized herpesvirus-associated fibrotic lung disease. Vet. Pathol. 44:849-862.

Wong D.M., Belgrave R.L., Williams K.J., Del Piero F., Alcott C.J., Bolin S.R., Marr C.M., Nolen-Walston R., Myers R.K. \& Wilkins P.A. 2008. Multinodular pulmonary fibrosis in five horses. J. Am. Vet. Med. Assoc. 232:898905. 